\title{
Self Esteem and Moral Intelligence in Adolescents
}

\author{
Nawang Warsi Wulandari \\ Marthen Pali \\ Imanuel Hitipeuw \\ Adi Atmoko \\ Doctoral Student \\ State University of Malang \\ Indonesia
}

\begin{abstract}
The purpose of this study is to know whether there is/isn't an effect of self-esteem on moral intelligence in adolescents. The subjects in this research are the adolescents of Junior High School as many as 116 people. The measurement instrument used in this research is the moral intelligence scale and the scale of self-esteem.The results of the validity test on the research instrument obtained the data that at the scale of moral intelligence there are 34 valid items and on the scale of self-esteem there are 27 valid items. The reliability test of each scale uses the Alpha Cronbach formula. The reliability test results show that the scale of moral intelligence (0.887) and the scale of self-esteem (0.906), including very reliable.The data in this research are analyzed by using the simple regression techniques. The results of data analysis obtained $F=40.500$ with a significance of 0.000. This shows that there is a significant effect of selfesteem on the moral intelligence. The effective contribution of self-esteem to the moral intelligence is 0.262.This shows that the range influence of social interaction on the moral intelligence is $26.2 \%$, while $73.8 \%$ is influenced by the other factors. The results of this study can be used as a consideration for choosing a method in an effort to increase the moral intelligence in adolescents.
\end{abstract}

Keywords: self-esteem; moral intelligence; adolescents

\section{Introduction}

The moral problems are a very important problem for everyone, even for every nation. The nation's moral problems can affect the good and bad condition of a nation. This makes the moral problems as a crucial problem in all countries, including Indonesia. At present moral issues are a problem that demands the attention of various parties because of the many cases of the moral degradation that occur in this country, especially among adolescents.

Some cases of the moral crises that occurred in Indonesia, among others: the National Commission for Child Protection/KPAI data shows that the 2018 student brawls were $1.1 \%$ higher than the last year. There were 41 cases (25.5\%) for the cases of child perpetrators of violence and bullying.The data from BKKBN (National Family Planning Coordinating Board) show that of the 2.4 million abortion cases in 2012, were carried out by the pre-marriage adolescents or Junior and Senior High School students. (http://health.liputan6. com/read/2062737/sepertiga-kasusaborsi-dilakukan-siswi-sma). The data from the National Anti Narcotics Agency (BNN) found that 50-60\% of the drug users in Indonesia are adolescents, among the students and college students.

The adolescents are often faced with the situations that contain the moral dilemmas. The situations that contain the moral dilemmas require the adolescents to choose what actions to take. In this case, the adolescents will use the moral values that he/she understands in determining which actions he/she will take.Some adolescents can choose the right action, while some others are less able to choose the right one. There are times when the adolescents understand morally which behavior is right and which is wrong, but the adolescents fail in behaving according to that understanding.

The failure of the adolescents in understanding and behaving in accordance with the moral values shows that the adolescents' moral intelligence is low. The low moral intelligence of adolescents can result in the destruction of the moral of the young generation.In the future, the young generation who lives now will lead the nation. The moral damage of the young generation who live at present can result in the collapse of the nation and the country/state of Indonesia in the future. 
The moral intelligence is the ability to understand right and wrong and a strong stance to think and behave according to the moral values (Borba, 2001). Borba stated about 7 main virtues, namelyemphaty, conscience, self control, respect, kindness, toleranceandfairness. These main virtues will help the children to face the ethical challenges and pressures that cannot be avoided in their lives. The main virtues also protect the children to always be on the right path and help them to act according to the morals. The moral intelligence includes a number of knowledge, desires and determinations and includes the individual ways of thinking, feeling and acting. Recognizing only the right from the wrong and not changing the feelings, abilities and actions of individuals (Clarken, in Beigi and Tabaeian, 2014).

Borba explains the children's moral intelligence in the seven aspects in the form of virtues possessed by a child who is morally intelligent, namely:

\section{a.Emphaty}

Empathy shows sensitivity to the needs and feelings of others. Empathy is the core of the moral emotion that helps individuals understand the feelings of others. With the empathy, the individuals become sensitive to the needs and feelings of others, by encouraging the individuals to help those who are in distress or pain and treat the people with affection. This empathy will prevent the individuals from taking actions that can hurt the others.

\section{b.Conscience}

Conscience shows the tendency of individuals to dare to admit mistakes and say sorry or apology. The conscience will help the individuals to choose the right path, to stay on a good moral path and to feel guilty when deviating from the proper path. The conscience will protect the individuals from the bad influences and be able to act right. This conscience is the foundation for the development of honesty, responsibility, and high self-integrity.

\section{c. Self-control}

Self-control shows the ability of individuals to do self-control of themselves. Self-control will help the individuals to resist the internal urge and to think before acting. Self-control will help the individuals become independent in controlling their own actions. This will evoke a compassionate and kindly attitude because the individuals have the awareness to attach importance to the needs of others (the altruistic attitude).

\section{d.Respect}

Respect shows the tendency to treat the others with respectful even though it is different. Respect encourages the individuals to be kind and respectful of others. Respect directs the individuals to treat the others as the individuals want to be treated. This will make the individuals not act rude, unfair and hostile. This respect will make the individuals pay attention to the rights and feelings of the others and to respect themselves.

\section{e. Kindness}

Kindness shows the ability to always show a favor and attention to the others with the sample of the role models from the parents or teachers. Kindness helps the individuals to be able to show the concern for the well-being and the feelings of others. Children will be more compassionate, not too selfish and realize good deeds as the right thing to do. This kindness makes the individuals think more about the needs of the others, to show concern, to provide the assistance to the people who need and to protect the people who are struggling in pain.

\section{f. Tolerance}

Tolerance shows a toleration to the others, regardless of the differences. Tolerance makes the individuals able to appreciate the differences in quality in the others, opening up to the new views and beliefs, respecting the others without distinction. This virtue will make the children treat the others well and comprehensively, opposing hostility, cruelty, bigotry and respecting the people based on the character of the others have.

\section{g.Fairness}

Fairness shows a strong sense of the justice. Fairness guides the children to treat the others well, impartially and fairly. This makes the individuals to obey the rules, want to take turns and share and also listen to all parties openly before giving an assessment. The individuals will be encouraged to defend those who are treated unfairly and to demand that everyone should be treated equally.

One of the factors that influence the moral development is the self-esteem. Baron and Byrne (1991) stated that selfesteem is defined as an individual attitude about him/herself, including self- evaluation in positive and negative dimensions. In general, most of the self-esteem refers to positive self-evaluations of the individuals.

Heatherton, T. F., and Polivy, J (1991) said that there are 3 main components of the self-esteem, namely: 
a. Performance self-esteem,it refers to the someone's feelings for the general competence and includes the intellectual abilities, school performance, capacity for self-regulation, self-confidence, self-efficacy and independence. The individuals who have high self-esteem performance believe that they are smart and capable.

b. Social self-esteem, it refers to how the individuals believe that the other people accept the individuals themselves. When the individuals believe that the other people, especially the significant persons respect and honor the individuals, then the individuals will have higher social self-esteem. The individuals who have low social self-esteem often experience the social anxiety. Those individuals are attentive to the individuals image, and those individuals are concerned about how the other people perceive those individuals.

c. Physical self-esteem,it refers to how the other people view the physical, including the sports abilities, physical attractiveness, body image (such as the physical stigma, also the feelings about race and ethnicity).

The elements that are proposed by Heatherton, T. F., and Polivy, J, for the next plan will be used to compile the instrument for measuring the self-esteem in this research.

\section{Research Methods}

This research is non-experimental research, because it does not give any treatment to the variables studied. This research will take measurements in the natural settings (Gall, et al., 2003). This research aims to know whether there is an influence of the social interaction on the moral intelligence in adolescents. This research also included the causal relationship study. Gall et al (2003) stated that the causal relationship study is a research that also explains the level of influence between the variables, in addition to explaining the relationship between the variables. Thus, this research uses a non-experimental research design with a causal relationship study type.

The population in this research was all students of the Malang Public/State Junior High School 24 with a total of 725 students. The sample in this study was $8^{\text {th }}$ grade (second year) students with a total of 116 students. The sampling technique that was used in this research was the purposive random sampling. The criteria that must be fulfilled by the sample are 13-14 years old and in the $8^{\text {th }}$ grade students (second year).

The measuring instrument that is used to measure the moral intelligence is the moral intelligence scale and the scale of self-esteem. The scale of moral intelligence that was used in this research was compiled by the researchers based on the aspects of moral intelligence from Borba (2001). The scale of self-esteem in this research was compiled by the researchers based on the aspects of the self-esteem from Heatherton, T. F., and Polivy, J (1991).

The results of the calculation of the validity of the moral intelligence scale test which amounted to 42 items, then, it could be obtained a number of fall items totaling are 8 items. An item can be said to be valid if the correlation value is $>0.300$ while an item can be said to be invalid if the tool gets a value of $<0.300$. The correlation coefficient for the valid item moves from 0.304 to 0.581 and the invalidity correlation coefficients move from 0.046 to 0.289 . The results of the calculation of the validity of the self-esteem scale which amounted to 32 items, it has obtained a number of items as many as 5 items. The correlation coefficient for valid item moves from the numbers: 0.309 to 0.661 , while the items that fall move at the numbers 0.187 to 0.284 .

The reliability test in the research for each scale is used an Alpha Cronbach formula, where the reliability coefficient is in the range of 0.00-1.00. The reliability coefficient is stated to be higher or more reliable if the reliability coefficient is close to 1.00.The reliability test results of the moral intelligence scale were 0.887 and the self-esteem scale was 0.906 . The results of these calculations are then adjusted to Guillford's reliability rules (Sugiyono, 2007). Based on these criteria, the scale of the moral intelligence and the scale of self-esteem are very reliable. The Guillford reliability criteria are presented in the following table.

Table 1. The Guillford Reliability Criteria

\begin{tabular}{ccc}
\hline No & Interval & Criteria \\
\hline 1. & $<2.00$ & Not Reliable \\
2. & $0.200-0.399$ & Less Reliable \\
3. & $0.400-0.599$ & Quite Reliable \\
4. & $0.600-0.799$ & Reliable \\
5. & $0.800-1.00$ & Very Reliable \\
\hline
\end{tabular}

The procedure carried out in this research is (a) preparing the measuring instruments that will be used in this research; (b) preparing a data collection schedule for the research subjects which are divided into 8 classes; (c) the researcher meets directly with the research subjects in accordance with a predetermined schedule; (d) the researcher explains how to work the measuring instrument that is used; 
(e) the researcher asks the research subjects to work on the measurement scales by giving a check list; (f) the researcher will give scoring and tabulating on the measurement scales; (g) the research data is ready to be analyzed.

The data in this research will then be processed by using the simple regression analysis techniques. This technique is used because the purpose of this research is to find out whether there is an effect of the variables of self-esteem on the moral intelligence variables.

\section{Research Result}

Regression test results obtained $F=40,500$ with sig $=0,000$. This shows that there is an effect of self esteem on the moral intelligence. The effect is indicated by $\mathrm{R}$ Square $=0.262$. This shows that the effect of self esteem on the moral intelligence is $26.2 \%$ and the rest is influenced by the other factors which is $73.8 \%$. The results of the regression test calculations and the magnitude/dimensions of the effective contribution are presented in the following table.

\section{Table 4. Regression Test Results}

\begin{tabular}{|c|c|c|c|c|c|c|}
\hline \multirow{2}{*}{\multicolumn{2}{|c|}{ Model }} & \multicolumn{3}{|c|}{ ANOVA $^{a}$} & \multirow[b]{2}{*}{$\mathrm{F}$} & \multirow[b]{2}{*}{ Sig. } \\
\hline & & Sum of Squares & df & Mean Square & & \\
\hline 1 & Regression & 6075,819 & 1 & 6075,819 & 40,500 &, $000^{\mathrm{b}}$ \\
\hline & Residual & 17102,483 & 114 & 150,022 & & \\
\hline & Total & 23178,302 & 115 & & & \\
\hline
\end{tabular}

a. Dependent Variable: KM

b. Predictors: (Constant), SE

Tabel 5. The Magnitude/Dimensions of the Effective Contribution Model Summary

\begin{tabular}{lr|r|r|r} 
Model & R & R Square & $\begin{array}{c}\text { Adjusted R } \\
\text { Square }\end{array}$ & $\begin{array}{c}\text { Std. Error of the } \\
\text { Estimate }\end{array}$ \\
\hline 1 &, $512^{\mathrm{a}}$ &, 262 &, 256 & 12,248 \\
\hline
\end{tabular}

a. Predictors: (Constant), SE

\section{Discussion}

The results of this research indicate that there is an effect of self- esteem on the moral intelligence. Self-esteem is basically how the individual's perception of him/herself and how valuable the individual is to the others, includes the self-evaluation in the positive and negative dimensions. The self-esteem affects the individual trust in the others, the individual relationships with others, on the individual work and almost in all parts of an individual's life. The positive self-esteem will give strength and flexibility to the individuals to be responsible for their lives without fear of being rejected.

In this research, the adolescent self-esteem is a teenager's perception of him/herself. In this case, the perception of adolescents is not always in accordance with the reality. There are times when the adolescents' perceptions are in accordance with the reality because the adolescents can correctly perceive success (achievement) or failure (its limitations). The adolescents can have a good self-esteem when they can perceive their success or failure appropriately.The inaccuracy of adolescents in perceiving success or failure can make the adolescents have low selfesteem. There are times when the adolescents also perceive inappropriately, for example, they are too overestimating or too underestimating themselves. This can indicate the superiority towards the others, arrogant, excessive and unreasonable (Santrock, 2007).

The development of the social relations which has carried out by the adolescents, having makes its own impact on the development of adolescents self-esteem. The assessments made by their friends are becoming increasingly important for the adolescents. The emotional support and social agreement in the form of confirmation from the others can have a strong influence on the adolescent self-esteem (Harter, in Santrock, 2007).

The problems in adolescent self-esteem can cause problems in their behavior. In a study, the low self-esteem that adolescents have relates to the violent thoughts on the adolescents (Harter \& McCarley, in Santrock, 2007). The adolescents with low self-esteem always need the approval from the others in deciding something. This makes the adolescents less able to decide independently when they are in a situation of moral dilemma.A longitudinal study shows that the need to receive the approval from others correlates negatively with the level of moral behavior (in Bern, 2010). The greater the dependence on respect from the others, then the individuals will be able to engage in antisocial behavior and illicit substance abuse (Bern, 2010). 
In adolescents peer evaluations show the increase of their importance. A study shows that the classmate support is more important than the support of close friends (Santrock, 2003). The low self-esteem can make the adolescents feel emotionally uncomfortable and can even cause the adolescents to feel depressed, experience delinquency to suicide.

The research conducted by Lee and Cho (2014) shows that self-esteem influences the adolescent delinquency behavior. The adolescents who have high self-esteem will choose the problem solving that is oriented on that problem. The adolescents who have low self esteem tend to choose the problem solving by emotionally.

Some researches that support this opinion include the research conducted by Lee and Cho (2014). The research was conducted on adolescents and aims to examine the effect of adolescent self-esteem on the delinquency behavior of themselves. The results of the research indicate that self-esteem influences the adolescent delinquency behavior. The adolescents who have high self-esteem will choose the problem solving that is oriented on that problem. The adolescents who have low self-esteem tend to choose the problem solving by emotionally.

The other research was conducted by Uba, Ikechukwu, Yaacob, S.N, Talib, M.A, Mofrad, S and Abdullah, R (2013). This research was conducted with 352 adolescents aged 13-18 years in Nigeria. This study aims to determine the correlation between stress, self esteem and the illicit substance abuse.The results of this research indicate that there is a negative correlation between self-esteem and substance abuse. The higher a person's self esteem, the less likely he/she is to be involved in substance abuse, whereas the lower a person's self esteem, the more likely he/she is to be involved in substance abuse.

Almost the same research was also carried out by Donnelan, M.B., Trzesniewski, K.H., Robins, R.W, Moffitt, T.E and Caspi, A. (2005). The research was conducted in 292 participants by age 11-14 years. The research aims to know the correlation between the self-esteem and externalizing problems, such as aggression, antisocial behavior and delinquency.The results show that there is a negative correlation between the self-esteem and parent reports and teacher reports regarding the externalizing problems. The individuals with low self esteem are more involved in antisocial behavior as delivered by the parents and teachers, and vice versa.

\section{Conclusion}

The results of this research are the influence of the self-esteem on the moral intelligence in the adolescents. The accuracy of adolescents in perceiving their success and failure will make adolescents more independent in determining their behavior according to their moral values when facing a moral dilemma.The influence of self esteem on the moral intelligence is $26.2 \%$. This shows that besides the self esteem, there are still other factors that affect the moral intelligence by $73.8 \%$.

\section{Bibliography}

Baron, R.A. \& Byrne, D. 1991. Social Psychology : Understanding Human Interaction. (6th ed). Boston, MA : Allyn \& Bacon.

Berns, R.M. 2010. Child, Family, School, Community : Socialization and Support. Belmont : Thompson Learning, Inc. Borba, M. 2001. Building Moral Intelligence. San Fransisco : Josey-Bas

Clarken, R.H., Moral Intelligence in the Schools. Paper presented at the annual meeting of The Michigan Academy of Sciences, Art and Letters. Wayne State University, Detroit, MI, March 20, 2009.

Donnelan, M.B., Trzesniewski, K.H., Robins, R.W, Moffitt, T.E and Caspi, A. 2005. Low Self Esteem is Related to Aggression, Antisocial Behavior, and Deliquency. American Psychological Society, Volume 16-number 4.

Gall, M. D., Gall, J. P., and Borg, W. R. 2003. Educational Research: An Introduction (7th ed). Boston: A \& B Publications

Heatherton, T. F., \& Polivy, J. 1991. Development and Validation of a Scale for Measuring State Self-Esteem. Journal of Personality and Social Psychology, 60, 895-910.

Lee, M.J., Cho, S.J. 2014. Effects of Teenager Self Esteem on Delinquency. Advanced Science and Technology

Letters Vol. 68 (Bioscience and Medical Research 2014), pp 38-42. http://dxdoi.org/10.14257/astl.2014.68.10

Santrock, JW. 2003. Adolesence : An Introductional (6st edition). USA: McGraw Hill.

Santrock, JW. 2007. Remaja. Jilid 1. Jakarta : Penerbit Erlangga

Uba, Ikechukwu, Yaacob, S.N, Talib, M.A, Mofrad, S and Abdullah, R. 2013. Effect of Self Esteem in The Relationship between Stress and Substance Abuse among Adolescents : A Mediation Outcome. International Journal of Social Science and Humanity, Vol. 3, No. 3, May 2013. 